\title{
The Sensory Abnormalities and Neuropsychopathology of Autism and Anxiety
}

\author{
Sirisha K. Gara ${ }^{1}$, Ashok G. Chhetri ${ }^{2}$, Montaser Alrjoob ${ }^{3}$, Sassi Ashraf Ali Abbasi ${ }^{1}$, Ian H. Rutkofsky ${ }^{4}$ \\ 1. Primary Care, California Institute of Behavioral Neurosciences and Psychology, Fairfield, USA 2. Primary Care, \\ Department of Research, California Institute of Behavioral Neurosciences and Psychology, Fairfield, USA 3. Internal \\ Medicine, California Institute of Behavioral Neurosciences and Psychology, Fairfield, USA 4. Psychiatry, California \\ Institute of Behavioral Neurosciences and Psychology, Fairfield, USA
}

Corresponding author: Sirisha K. Gara, drsirishagara@gmail.com

\begin{abstract}
Autism spectrum disorder (ASD) is a developmental disorder of interpersonal communications and restricted interest and deficits in sensory and social interactions. It co-occurs with anxiety and mostly in $30 \%$ of cases related to specific phobia. This review article summarises the sensory association between anxiety and ASD. The role of emotions and neurobiology discussed and sensory over-reactivity (SOR) was related to ASD and anxiety. PubMed database systematically searched for related articles on ASD and anxiety. The keywords used are autism spectrum disorder, autism spectrum disorder and emotion, anxiety disorder, sensory in autism and anxiety, and psychopathology. The results were most significant and related to the sensory association between ASD and anxiety. Out of 19 studies discussed, there were eight systematic reviews with meta-analysis, seven systematic reviews, three traditional reviews, and one included both systematic reviews with randomized controlled trials (RCTs). However, due to possible limitations and considerations, like small sample size and few clinical trials; hence, further recommendations to randomized clinical trials and cohort studies warranted. This review article helps scientists to plan and focus on necessary studies and possible screening for the disease to improve possible clinical outcomes. People gain awareness of the disease. Early recognition, as well as educational, behavioral, and family therapy, might decrease symptoms and support learning and development in children.
\end{abstract}

Received 02/02/2020

Review began 03/06/2020 Review ended 05/12/2020 Published 05/12/2020

\section{() Copyright 2020}

Gara et al. This is an open access article distributed under the terms of the Creative Commons Attribution License CC-BY 4.0., which permits unrestricted use, distribution, and reproduction in any medium, provided the original author and source are credited.
Categories: Neurology, Pathology, Psychology

Keywords: anxiety disorder, autism spectrum disorder, autism spectrum disorder and anxiety disorder, sensory in autism and anxiety, autism spectrum disorder and emotion, anxiety and autism linked to emotion, autistic disorder and anxiety connected to psychopathology

\section{Introduction And Background}

Autism spectrum disorder (ASD) is a neurological disease characterized by deficits in social communication as well as repetitive behaviors and restricted interests. ASD is a neurodevelopmental disorder with increased prevalence in children and adults over the past few decades. Specific phobia is associated with ASD in $30 \%$ cases and includes obsessive-compulsive disorder 17\%, social anxiety disorder, and agoraphobia 17\%, generalized anxiety disorder $15 \%$, separation anxiety disorder $9 \%$, and panic disorder $2 \%$. Based on parent analysis, $25.2 \%$ of boys and $19.5 \%$ of girls with ASD are out of margin for generalized anxiety disorder (teacher report: $23.3 \%$ and $20.8 \%$ for boys and girls, respectively). For separation anxiety, $6.7 \%$ of boys and $7.1 \%$ of girls were above the screening threshold via parent-report (teacher report: $13.8 \%$ and $8.0 \%$, respectively) [1-3].

Severe signs and symptoms of anxiousness frequently co-occur in ASD [4,5]. Nearly $40 \%$ of human beings had elevated levels of anxiousness, and it is related to comorbidity in both children and adults. The anxiousness determined right here is regular with previous evaluations of the ASD literature. In addition to the core signs and symptoms of ASD; comorbid psychiatric prerequisites are highly prevalent, increasing impairment, and complicating prognosis and treatment [6-8]. There is widespread evidence that people with ASD are at heightened danger for anxiety and anxiety disorders, which can propose chronic distress, exacerbate ASD symptoms, and amplify behavioral troubles. The sensory feature is associated with repeated touching or painful response to objects. Both extremes may show up in identical children [9-13].

This review mostly focuses on the sensory association between ASD and anxiety however conjointly discusses three ideas for understanding the event and maintenance of anxiety in ASD: (1) atypical sensory function, that is often enclosed within the diagnostic criteria for ASD; (2) problem identifying/labeling emotions (alexithymia), that has shown to be severe in ASD; and (3) neurobiology connected to anxiety and ASD. Whereas these ideas come back from completely different backgrounds, existing analysis shows that they are closely related. A significant challenge is to outline how these ideas diverge biologically. Improved understanding of the psychological feature and emotional mechanisms that underlie anxiety in ASD could give insight relating to the psychopathology and psychophysiology of each condition and make additional specific targets for biological and behavioral intervention [14-16]. 
After understanding the ideas and prevalence of ASDs and anxiety, we believe that there is a need to evaluate the link between ASD and anxiety and the way they are connected. Because of the increasing prevalence of tension in ASDs, there is a necessity to grasp the factors taking part in a task for any management and treatment. This review aims to summarize the recent literature related to abnormalities in sensory functioning in people with ASD, together with proof linked to the neurobiology of those symptoms, their clinical correlation, and their treatment. Abnormalities in responses to sensory stimuli are incredibly prevalent in people with ASD. The underlying neurobiology of those symptoms is unclear, however many theories projected linking potential etiologies of neural pathology with well-known abnormalities in brain structure and performance that are related to ASD [17]. The following symptoms characterize autism spectrum disorder (Figure 1).

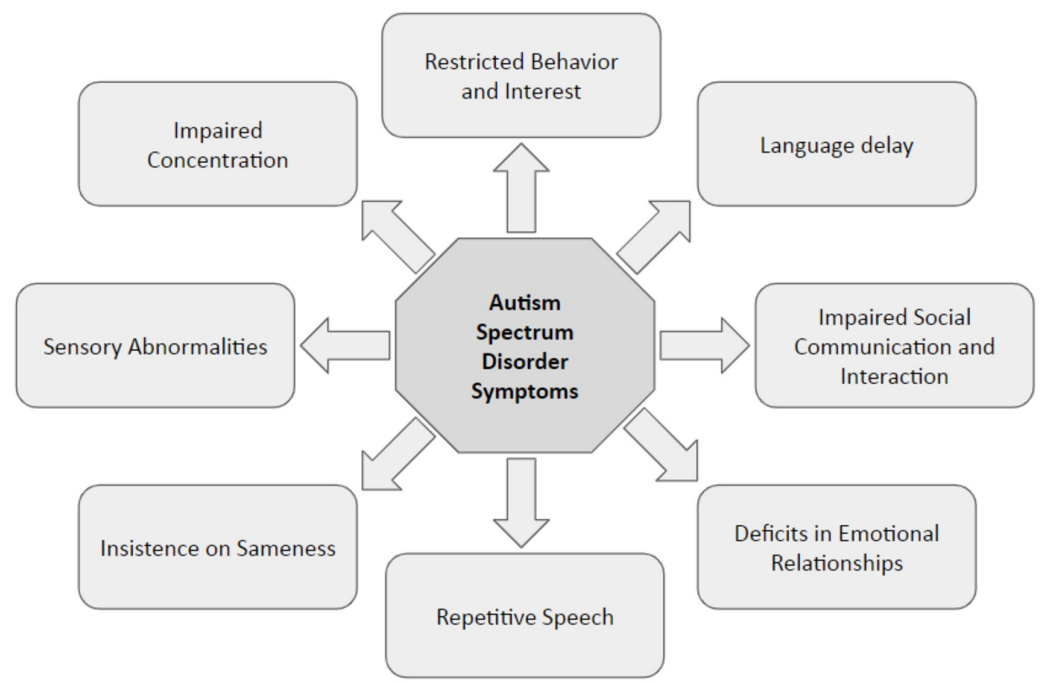

FIGURE 1: ASD symptoms

ASD, autism spectrum disorder

\section{Review}

\section{Methods and results}

PubMed database systematically searched using the keywords anxiety disorder, autism spectrum disorder, autism spectrum disorder and anxiety disorder, sensory in autism and anxiety, autism spectrum disorder and emotion, anxiety, and autism linked to emotion. After a search with the exclusion and inclusion criteria applied to full text and articles reviewed within the last 10 years yielded the following results: anxiety disorder 60537, autism spectrum disorder 22408, autism spectrum disorder and anxiety disorder 1572, sensory in autism and anxiety 160 , anxiety and autism linked to emotion 70 . Combined mesh keywords used narrowed the search to the results below. Autistic disorder and anxiety 132, autistic disorder, and anxiety connected with psychopathology 40.

All the duplicate and impertinent articles were excluded from the study. All types of clinical studies included without limiting to a specific category. The reviews restricted within the last 10 years. Google Scholar has conjointly been used as a reference wherever applicable, along with PubMed. The following studies are related to the sensory association between autism and anxiety (Table 1 ).

\begin{tabular}{|c|c|c|c|c|c|c|}
\hline \# & $\begin{array}{l}\text { Author } \\
\text { (Year) }\end{array}$ & $\begin{array}{l}\text { Type of } \\
\text { study }\end{array}$ & Country & $\begin{array}{l}\text { Study's } \\
\text { focus }\end{array}$ & Findings & Summary \\
\hline 1 & $\begin{array}{l}\text { White et al. } \\
\text { (2009) [6] }\end{array}$ & $\begin{array}{l}\text { Systematic } \\
\text { review }\end{array}$ & USA & $\begin{array}{l}\text { Autism } \\
\text { Anxiety }\end{array}$ & A systematic review of 40 papers. & $\begin{array}{l}\text { Prevalence, } \\
\text { treatment, and } \\
\text { methodology. }\end{array}$ \\
\hline 2 & $\begin{array}{l}\text { Green } \\
\text { and Ben- } \\
\text { Sasson } \\
(2010)[30]\end{array}$ & Review & USA & $\begin{array}{l}\text { Anxiety } \\
\text { Sensory } \\
\text { over- } \\
\text { reactivity }\end{array}$ & Theoretical models between SOR and anxiety. & $\begin{array}{l}\text { A strong } \\
\text { association } \\
\text { between SOR } \\
\text { and anxiety. }\end{array}$ \\
\hline & & & & & & The link \\
\hline
\end{tabular}




\begin{tabular}{|c|c|c|c|c|c|c|}
\hline 3 & $\begin{array}{l}\text { van } \\
\text { Steensel et } \\
\text { al. (2011) [3] }\end{array}$ & $\begin{array}{l}\text { Systematic } \\
\text { review and } \\
\text { meta- } \\
\text { analysis }\end{array}$ & Netherlands & $\begin{array}{l}\text { Anxiety } \\
\text { and ASDs }\end{array}$ & $\begin{array}{l}\text { Identified } 31 \text { studies with } 2121 \text { people and conducted } \\
\text { standard questionnaires or diagnostic interviews, } \\
\text { phobia }(29.8 \%) \text { followed by OCD }(17.4 \%) \text { and social } \\
\text { anxiety disorder (16.6\%). }\end{array}$ & $\begin{array}{l}\text { between the } \\
\text { specific anxiety } \\
\text { disorder and } \\
\text { ASD subtype } \\
\text { has been } \\
\text { identified. }\end{array}$ \\
\hline 4 & $\begin{array}{l}\text { Green et al. } \\
\text { (2012) [33] }\end{array}$ & $\begin{array}{l}\text { Systematic } \\
\text { review with } \\
\text { meta- } \\
\text { analysis }\end{array}$ & USA & $\begin{array}{l}\text { Anxiety } \\
\text { Sensory } \\
\text { over- } \\
\text { reactivity } \\
\text { in ASD in } \\
\text { toddlers }\end{array}$ & $\begin{array}{l}\mathrm{n}=149 \text { toddlers. Paired } \mathrm{t} \text { sample test, } \mathrm{t}(148)=-3.00, \mathrm{p} \\
=.003 \text { but mean SOR scores were stable across time, } \\
\mathrm{t}(148)=-1.10, \mathrm{p}=0.275\end{array}$ & $\begin{array}{l}\text { SOR predicts a } \\
\text { change in } \\
\text { anxiety across } \\
\text { toddlerhood. }\end{array}$ \\
\hline 5 & $\begin{array}{l}\text { Green et al. } \\
\text { (2013) [31] }\end{array}$ & $\begin{array}{l}\text { Systematic } \\
\text { review }\end{array}$ & USA & $\begin{array}{l}\text { ASD, } \\
\text { sensory } \\
\text { stimuli }\end{array}$ & $\begin{array}{l}\mathrm{n}=25 \text { high functioning youth age } 25 \\
\text { assessed aversive auditory and visual stimuli during a } \\
\text { functional MRI scan. }\end{array}$ & $\begin{array}{l}\text { ASD } \\
\text { associated with } \\
\text { increased } \\
\text { activation of } \\
\text { the } \\
\text { hippocampus, } \\
\text { amygdala, and } \\
\text { orbitofrontal } \\
\text { cortex. }\end{array}$ \\
\hline 6 & $\begin{array}{l}\text { Ben-Sasson } \\
\text { et al. (2013) } \\
\text { [18] }\end{array}$ & $\begin{array}{l}\text { Systematic } \\
\text { review with } \\
\text { meta- } \\
\text { analysis }\end{array}$ & Israel & $\begin{array}{l}\text { ASD SOR } \\
\text { Stress in } \\
\text { Toddlers }\end{array}$ & $\begin{array}{l}\mathrm{n}=175 . \text { ADOS, MSEL composite score, ISTEA anxiety } \\
\text { symptoms BAI, CES-D at time } 1 \text { explained } 39-45 \% \text { of } \\
\text { the variance.FLIS and PSI did not change over time. }\end{array}$ & $\begin{array}{l}\text { SOR is related } \\
\text { to stress. }\end{array}$ \\
\hline 7 & $\begin{array}{l}\text { Case-Smith } \\
\text { (2015) [19] }\end{array}$ & $\begin{array}{l}\text { Systematic } \\
\text { review }\end{array}$ & USA & $\begin{array}{l}\text { Autism } \\
\text { and } \\
\text { sensory } \\
\text { processing }\end{array}$ & $\begin{array}{l}\text { Two randomized controlled trials and } 19 \text { studies } \\
\text { reviewed and } 15 \text { were related to therapy. }\end{array}$ & $\begin{array}{l}\text { Sensory } \\
\text { integration } \\
\text { therapy } \\
\text { reduced } \\
\text { sensory } \\
\text { problems. }\end{array}$ \\
\hline 8 & $\begin{array}{l}\text { Sullivan et } \\
\text { al. (2014) } \\
\text { [20] }\end{array}$ & $\begin{array}{l}\text { Systematic } \\
\text { review }\end{array}$ & USA & $\begin{array}{l}\text { Anxiety } \\
\text { Migraine } \\
\text { Sensory } \\
\text { Over- } \\
\text { reactivity }\end{array}$ & $\begin{array}{l}81 \text { children aged } 7-17 \text { years. ASD and migraines } \\
p<0.01 \text { sensory hyperreactivity and anxiety } \rho=0.31, p \\
=0.005 \text {. }\end{array}$ & $\begin{array}{l}\text { Greater SOR } \\
\text { with ASD and } \\
\text { migraines. }\end{array}$ \\
\hline 9 & $\begin{array}{l}\text { Kerns et al. } \\
\text { (2014) [5] }\end{array}$ & $\begin{array}{l}\text { Systematic } \\
\text { review and } \\
\text { meta- } \\
\text { analysis }\end{array}$ & USA & $\begin{array}{l}\text { Anxiety } \\
\text { and autism } \\
\text { spectrum } \\
\text { disorders } \\
\text { in youth }\end{array}$ & $\begin{array}{l}\mathrm{n}=59,7-17 \text { years, } \mathrm{Q}>60 \text { with } \text { ASD conducted semi- } \\
\text { structured interviews and parent reports. } 17 \% \\
\text { traditional anxiety, } 15 \% \text { atypical, and } 31 \% \text { both. }\end{array}$ & $\begin{array}{l}\text { Supported the } \\
\text { association } \\
\text { between } \\
\text { Anxiety and } \\
\text { ASD. }\end{array}$ \\
\hline 10 & $\begin{array}{l}\text { Green et al. } \\
\text { (2015) [38] }\end{array}$ & $\begin{array}{l}\text { Systematic } \\
\text { review }\end{array}$ & USA & $\begin{array}{l}\text { ASD } \\
\text { Sensory } \\
\text { over- } \\
\text { reactivity }\end{array}$ & $\begin{array}{l}\text { Mean age } 14 \text { years. } n=38 \text {. Functional MRI imaging } \\
\text { was done. Participants with ASD have a stronger } \\
\text { activation of the amygdala } p<0.05 \text {. ASD with the SOR } \\
\text { subgroup showed decreased neural habituation than } \\
\text { without SOR. } z>1.70, p<0.05 \text {. }\end{array}$ & $\begin{array}{l}\text { Youth with } \\
\text { ASD show } \\
\text { sensory limbic } \\
\text { hyperreactivity } \\
\text { through } \\
\text { prefrontal } \\
\text { downregulation } \\
\text { of the } \\
\text { amygdala. }\end{array}$ \\
\hline \multirow[t]{2}{*}{11} & $\begin{array}{l}\text { Lecavalier et } \\
\text { al. (2014) } \\
\text { [11] }\end{array}$ & $\begin{array}{l}\text { A } \\
\text { systematic } \\
\text { review and } \\
\text { clinical } \\
\text { trials }\end{array}$ & USA & $\begin{array}{l}\text { Anxiety } \\
\text { ASD }\end{array}$ & $\begin{array}{l}\text { Over a 14-month period, monthly conferences were } \\
\text { held and two face-to-face meetings were scheduled. } \\
38 \text { published studies, } 10 \text { assessment measures were } \\
\text { reviewed and four were appropriate for clinical trials. } \\
\text { Anxiety scales: ADAMS - 28-point scale, RCADS - } 47 \text { - } \\
\text { item scale, SCARED - } 41 \text {-item scale.CASI, MASC, } \\
\text { ADIS, PARS are 20-point scales useful for more clinical } \\
\text { trials. RCAMS is used for depression and anxiety. }\end{array}$ & $\begin{array}{l}\text { Anxiety in ASD } \\
\text { needs for } \\
\text { treatment. }\end{array}$ \\
\hline & & Systematic & & $\begin{array}{l}\text { Anxiety } \\
\text { and }\end{array}$ & & $\begin{array}{l}\text { Both children } \\
\text { with and }\end{array}$ \\
\hline
\end{tabular}




\section{Cureus}

\begin{tabular}{|c|c|c|c|c|c|c|}
\hline 12 & $\begin{array}{l}\text { Neil et al. } \\
\text { (2016) [21] }\end{array}$ & $\begin{array}{l}\text { review with } \\
\text { meta- } \\
\text { analysis }\end{array}$ & UK & $\begin{array}{l}\text { sensory } \\
\text { over- } \\
\text { reactivity } \\
\text { in children }\end{array}$ & $\begin{array}{l}64 \text { autistic and } 85 \text { typically developing children aged } \\
6-14 \text { years. Intolerance of uncertainty role in ASD. }\end{array}$ & $\begin{array}{l}\text { without autism } \\
\text { associated with } \\
\text { it. }\end{array}$ \\
\hline 13 & $\begin{array}{l}\text { Corbett et } \\
\text { al. (2016) } \\
\text { [22] }\end{array}$ & $\begin{array}{l}\text { Systematic } \\
\text { review with } \\
\text { meta- } \\
\text { analysis }\end{array}$ & USA & $\begin{array}{l}\text { ASD, } \\
\text { sensory } \\
\text { sensitivity }\end{array}$ & $\begin{array}{l}n=80, \text { Children between } 8 \text { and } 12 \text { years. ASD and } \\
\text { stress with cortisol levels assessed by } T \text { test and } \\
\text { ANOVA. PIP }[F(1,77)=5.77, p=0.02] . P(r=-0.242, p \\
=0.03) \text {, and positively correlated with SSS }(r=0.273, p \\
=0.02), P(p<0.05) .\end{array}$ & $\begin{array}{l}\text { Stress relation } \\
\text { to SOR. }\end{array}$ \\
\hline 14 & $\begin{array}{l}\text { Kerns et al. } \\
\text { (2017) [23] }\end{array}$ & $\begin{array}{l}\text { Systematic } \\
\text { review with } \\
\text { meta- } \\
\text { analysis }\end{array}$ & USA & $\begin{array}{l}\text { Anxiety } \\
\text { ASD }\end{array}$ & $\begin{array}{l}\text { Sample of } 69 \text { youth with ASD, comorbid symptoms } \\
0.85-0.98, \kappa=0.67-0.91 \text {, anxiety like symptoms } 0.87- \\
0.95, K=0.77-0.90\end{array}$ & $\begin{array}{l}\text { Results } \\
\text { conclude the } \\
\text { ADIS/ASA } \\
\text { measures } \\
\text { anxiety in } \\
\text { youth with } \\
\text { ASD. }\end{array}$ \\
\hline 15 & $\begin{array}{l}\text { Uljarević et } \\
\text { al. (2017) } \\
\text { [24] }\end{array}$ & $\begin{array}{l}\text { Systematic } \\
\text { review with } \\
\text { meta- } \\
\text { analysis }\end{array}$ & AUS & $\begin{array}{l}\text { ASD, } \\
\text { anxiety } \\
\text { sameness }\end{array}$ & $\begin{array}{l}\text { Study between 71-year-old adolescents and younger } \\
\text { individuals with } n=71 \text {. IS associated with } E C(r=-0.39 \text {, } \\
p=0.001) \text { and anxiety }(r=0.45, p<0.001) \text {.and anxiety } \\
\text { was in turn associated with } E C(r=0.44, p<0.001) \text {. }\end{array}$ & $\begin{array}{l}\text { First revealed } \\
\text { the relation } \\
\text { between ASD } \\
\text { and anxiety. }\end{array}$ \\
\hline 16 & $\begin{array}{l}\text { South and } \\
\text { Rodgers } \\
\text { \{2017) [25] }\end{array}$ & $\begin{array}{l}\text { Systematic } \\
\text { review }\end{array}$ & USA & $\begin{array}{l}\text { Autism } \\
\text { Anxiety } \\
\text { Sensory, } \\
\text { emotions }\end{array}$ & $\begin{array}{l}\text { Intolerance of uncertainty, Autism, Anxiety and } \\
\text { emotions }(n=76) \text {. }\end{array}$ & $\begin{array}{l}\text { Associations } \\
\text { and the need } \\
\text { for the } \\
\text { investigation. }\end{array}$ \\
\hline 17 & $\begin{array}{l}\text { Postorino et } \\
\text { al. (2017) } \\
\text { [26] }\end{array}$ & Review & USA & $\begin{array}{l}\text { Anxiety } \\
\text { ASD OCD }\end{array}$ & Anxiety and OCD prevalence in ASD. & $\begin{array}{l}\text { Higher } \\
\text { correlation. }\end{array}$ \\
\hline 18 & $\begin{array}{l}\text { Hwang et al. } \\
\text { (2019) [27] }\end{array}$ & $\begin{array}{l}\text { Systematic } \\
\text { review }\end{array}$ & AUS & $\begin{array}{l}\text { Anxiety } \\
\text { and } \\
\text { sensory } \\
\text { sensitivity }\end{array}$ & $\begin{array}{l}\text { A sample size of } 176 \text { individuals with a mean age } 42 \\
\text { included in the study. }\end{array}$ & $\begin{array}{l}\text { Intolerance of } \\
\text { uncertainty in } \\
\text { anxiety and } \\
\text { SOR. }\end{array}$ \\
\hline 19 & $\begin{array}{l}\text { Bitsika et al. } \\
\text { (2019) [28] }\end{array}$ & $\begin{array}{l}\text { Systematic } \\
\text { review }\end{array}$ & AUS & $\begin{array}{l}\text { GAD ASD } \\
\text { Sensory } \\
\text { features }\end{array}$ & $\begin{array}{l}\text { Test conducted on a small sample size of } 150 \text { males } \\
\text { limited to age } 6 \text { to } 18 \text { years. }\end{array}$ & $\begin{array}{l}\text { Higher } \\
\text { association } \\
\text { between ASD } \\
\text { and GAD than } \\
\text { sensory. }\end{array}$ \\
\hline
\end{tabular}

\section{TABLE 1: Results}

References listed in the table also includes $[30,31,33,38]$

OCD, obsessive compulsive disorder; ASD, autism spectrum disorder; GAD, generalised anxiety disorder; ANOVA, analysis of variance; EC, effortful control; PIP, peer interaction paradigm; SOR, sensory over-reactivity

Anxiety scales

ADOS, Autism Diagnostic Observation Schedule; MSEL, Mullen Scales of Early Learning; ITSEA, Infant Toddler Social Emotional Assessment; BAI, Beck Anxiety Index; CES-D, Center for Epidemiological Studies Depression Inventory; PSI, Parenting Stress Index; FLIS, Family Life Impairment Scale; CASI, Children and Adolescent Symptom Inventory; MASC, Multidimensional Anxiety Scales for Children; ADIS, Anxiety Diagnostic Interview Scale; PARS, Pediatric Anxiety Rating Scale; ADAMS, Anxiety Depression and Mood Scale; RCADS, Revised Child Anxiety and Depression

Scale; SCARED, Screen for Child Anxiety Related Disorders; RCAMS, Revised Children's Manifest Anxiety Scales 


\section{- Autistic Disorder \\ - Asperger's Disorder \\ $\square$ Childhood Disintegrative Disorder \\ $\square$ Pervasive Developmental Disorder - NOS (PDD-NOS)}

\section{FIGURE 2: PDD types}

PDD, pervasive developmental disorder; NOS, not otherwise specified

Sensory Role in Autism and Anxiety

Anxiety issues lead to hyperarousal, hypervigilance, and bias, coupled with over-reactivity in ASDs. Hypervigilance recognized as a problem in risk-based emotional regulation. Signs and symptoms of hyperarousal in the control of emotions causes sensory over-reactivity (SOR). These signs and symptoms of anxiousness cause learning that is preservation and exacerbation of the cycle between anxiousness and SOR. It is the necessary model of nervousness that explains the SOR. Anxiety and associated SOR though they are not causally connected maintained by the treatment of an unknown variable dominant link that's via the amygdala that may be a neurohormonal correlation, whenever there's an associate activity of amygdala this nervousness, and SOR happens in people. Over responsivity to sensory stimuli may be a common symptom of the amygdala. ASDs are understudied, due to the reality it had been once only recently delivered to DSM-5 diagnostic criteria. Neural and behavioral over-reactivity associated with each sensory and emotional area in early existence with ASD. The atypical sensory process has been represented in the autism spectrum altogether, and there has been a tested relationship between sensory process, adaptive behaviors, and interest capabilities in teenagers with ASD. There was a vast influence on of these adaptive conduct and activity competencies on ASD. SOR may be a good predictor of the conventional behaviors in ASD and changes in anxiety [29-33].

Sensory Over-Reactivity

SOR is associated with gastrointestinal (GI) problems in teenagers with anxiety and ASD. Children with predominant symptoms of SOR are related to persistent GI troubles like pain abdomen, diarrhea, and bloating. Children with different kinds of GI issues were related to nervousness and SOR. Studying this sensory function has also led the researchers to discover an association with Williams syndrome (WS) and migraines. ASD and WS share common psychopathology touching on to sensory processing and repetitive behaviors. In ASD and WS, difficulties processing the sensory factors of the environment, repetitive behaviors, and high degrees of anxiety co-occur. Direct significant relationships between sensory elements and repetitive behaviors were observed solely for the ASD group. Sensory difficulties maintained by linear relationships related to repetitive behaviors in kids with ASD. In WS, the relationship is mediated via intolerance of uncertainty. The findings support that there is a complexity of the mechanisms underlying the link between sensory processing and repetitive behaviors across neurodevelopmental issues. Children with one type of GI problem had higher levels of anxiety and SOR. GI troubles and anxiety were strongly linked [34,35].

\section{Role of Emotions in ASD and Anxiety}

Alexithymia is related to a decreased interest to spot and describe one's feelings, which leads to reduced sympathy and an impaired ability to acknowledge the emotions. The degree of alexithymia predicted the eye fixation. In addition to social impairment, an emotional disturbance related to ASD. The anterior insula regulates the alexithymia, and the strength of the response is lesser in ASD, and there was a variation from healthy individuals. Empathy deficits in autism are related to emotions and not a feature of impaired social communications. The GABA and glutamate are the neurotransmitters involved in the neurohormonal mechanisms [36-38].

\section{Neurobiology in Anxiety and ASD}

In ASD, there has been a greater activation in the fundamental sensory areas like auditory and visual cortices and thalamus as in emotion processing regions like the amygdala, hippocampus, and prefrontal cortex. The thalamic response and amygdala influenced the higher cortical areas of anxiety. The amygdala sends the 
signal to the hippocampus and maintains conditioning and fear. The amygdala and the red nucleus of Stria Terminalis implicated in the characteristics of anxiety disorders. The amygdala and the red nucleus of the Stria Terminalis involved in the symptoms of anxiety disorders. Somatostatin-expressing neurons in the central amygdala (CEA) controls anxiousness through modulation of Stria Terminalis, a technique that mediated with the aid of dynorphin signaling in the CEA [39].

Therapy in Anxiety and ASD

The sensory association also helped in targeting cognitive behavioral therapy, which has proven to be effective in patients with anxiety and ASD. The cognitive-behavioral treatment helps children with ASD and anxiety, which includes psychoeducation, cognitive restructuring, self-talk, relaxation, and exposure to feared stimuli. A manualized CBT intervention has enhanced for the children with ASD by addressing adaptive skills and poor social skills in addition to the core anxiety problems. Psychopharmacological treatments with selective serotonin reuptake inhibitors have been effective in treating patients with anxiety. Autism is mostly associated with sensory and self-regulatory processes as controls, and massage therapy also played a beneficial role in managing the sensory symptoms in patients with anxiety. Early identification of the disease might improve the outcome in language, cognitive, and adaptive skills; hence, we have to develop a new screening tool for the disease [40-43]. Studying the relationship between SOR and anxiety in individuals with ASD by this diagnostic overlap helps in making the occupational therapists proceed with the treatment benefits with accuracy.

\section{Conclusions}

This review article's primary focus is the sensory association between ASD and anxiety and also the associated neuropathology. Once the association between ASD and anxiety established, it is essential to search out out if, to any extent, further factors are playing a role because it could be a leading cause and most outgrowing in youngsters. The main focus was on sensory association and also the emotional performance that helped in treating patients with ASD and anxiety. SOR plays an essential part in the discussion. The pathway association with autism and anxiety helped in the strengthening of the relationship between autism and anxiety.

SOR plays a critical role in the debate. This review not only solely summarises all the possible links the sensory, emotional, and neurobiology in autism and anxiety; however, it also reveals the sensory association with Williams syndrome and Gastrointestinal disorders. This analysis helps improve the treatment outcomes among individuals with autism spectrum disorders and anxiety. However, additional clinical trials and cohort studies are necessary to strengthen the effect of the association between them. The new screening tools for further diagnostic purposes can improve clinical outcomes through early treatment and management.

\section{Additional Information \\ Disclosures}

Conflicts of interest: In compliance with the ICMJE uniform disclosure form, all authors declare the following: Payment/services info: All authors have declared that no financial support was received from any organization for the submitted work. Financial relationships: All authors have declared that they have no financial relationships at present or within the previous three years with any organizations that might have an interest in the submitted work. Other relationships: All authors have declared that there are no other relationships or activities that could appear to have influenced the submitted work.

\section{Acknowledgements}

Thank you CIBNP and Dr.Hassaan Tohid

\section{References}

1. Fombonne E: The epidemiology of pervasive developmental disorders . Pediatr Res. 2009, 65:591-598. 10.1203/PDR.0b013e31819e7203

2. Morbidity and Mortality Weekly Report: Surveillance Summaries: Prevalence of Autism Spectrum Disorders: Autism and Developmental Disabilities. Centers for Disease Control and Prevention. 2012, 61:1-19.

3. van Steensel FJ, Bögels SM, Perrin S: Anxiety disorders in children and adolescents with autistic spectrum disorders: a meta-analysis. Clin Child Fam Psychol Rev. 2011, 14:302-317. 10.1007/s10567-011-0097-0

4. Kerns CM, Kendall PC: Autism and anxiety: overlap, similarities and differences, in Handbook of Autism and Anxiety, pp 75-89. Davis TE, White SW, Ollendick T (ed): Springer, New York, NY; 2014.

5. Kerns C, Kendall PC, Berry L, et al.: Traditional and atypical presentations of anxiety in youth with autism spectrum disorder. J Autism Dev Disord. 2014, 44:2851-2861. 10.1007/s10803-014-2141-7

6. White SW, Oswald D, Ollendick T, Scahill L: Anxiety in children and adolescents with autism spectrum disorders. Clin Psychol Rev. 2009, 29:216-229. 10.1016/j.cpr.2009.01.003

7. Mazzone L, Ruta L, Reale L: Psychiatric comorbidities in Asperger syndrome and high functioning autism: diagnostic challenges. Ann Gen Psychiatry. 2012, 11:16. 10.1186/1744-859X-11-16

8. Mazzone L, Vitiello B: Psychiatric symptoms and comorbidities in autism spectrum disorder. Springer, 
Cham; 2016. 10.1007/978-3-319-29695-1

9. Hallet V, Lecavalier L, Sukhodolsky DG, et al.: Exploring the manifestations of anxiety in children with autism spectrum disorders. J Autism Dev Disord. 2013, 43:2341-2352. 10.1007/s10803-013-1775-1

10. Pugliese CE, White BA, White SW, Ollendick TH: Social anxiety predicts aggression in children with ASD: clinical comparisons with socially anxious and oppositional youth. J Autism Dev Disord. 2013, 43:12051213. 10.1007/s10803-012-1666-X

11. Lecavalier L, Wood JJ, Halladay AK, et al.: Measuring anxiety as a treatment endpoint in youth with autism spectrum disorder. J Autism Dev Disord. 2014, 44:1128-1143. 10.1007/s10803-013-1974-9

12. Wigham S, Rodgers J, South M, McConachie H, Freeston M: The interplay between sensory processing abnormalities, intolerance of uncertainty, anxiety and restricted and repetitive behaviours in autism spectrum disorder. J Autism Dev Disord. 2015, 45:943-952. 10.1007/s10803-014-2248-x

13. Watts SJ, Rodgers J, Riby D: A systematic review of the evidence for hyporesponsivity in ASD . Rev J Autism Dev Disord. 2016, 3:286-301. 10.1007/s40489-016-0084-y

14. Hashemi E, Ariza J, Rogers H, Noctor SC, Martínez-Cerdeño V: The number of parvalbumin-expressing interneurons is decreased in the medial prefrontal cortex in autism. Cereb Cortex. 2017, 27:1931-1943. 10.1093/cercor/bhw021

15. Kerns CM, Roux AM, Connell JE, Shattuck PT: Adapting cognitive behavioral techniques to address anxiety and depression in cognitively able emerging adults on the autism spectrum. Cogn Behav Pract. 2016, 23:329-340. 10.1016/j.cbpra.2016.06.002

16. Rodgers J, Hodgson A, Shields K, Wright C, Honey E, Freeston M: Towards a treatment for intolerance of uncertainty in young people with autism spectrum disorder: development of the Coping with Uncertainty in Everyday Situations (CUES@) programme. J Autism Dev Disord. 2017, 47:3959-3966. 10.1007/s10803-0162924-0

17. Hazen EP, Stornelli JL, O'Rourke JA, Koesterer K, McDougle CJ: Sensory symptoms in autism spectrum disorders. Harv Rev Psychiatry. 2014, 22:112-124. 10.1097/01.HRP.0000445143.08773.58

18. Ben-Sasson A, Soto TW, Martínez-Pedraza F, Carter AS: Early sensory over-responsivity in toddlers with autism spectrum disorders as a predictor of family impairment and parenting stress. J Child Psychol Psychiatry. 2013, 54:846-853. 10.1111/jcpp.12035

19. Case-Smith J, Weaver LL, Fristad MA: A systematic review of sensory processing interventions for children with autism spectrum disorders. Autism. 2015, 19: 133-148. 10.1177/1362361313517762

20. Sullivan JC, Miller LJ, Nielsen DM, Schoen SA: The presence of migraines and its association with sensory hyperreactivity and anxiety symptomatology in children with autism spectrum disorder. Autism. 2014, 18: 743-747. 10.1177/1362361313489377

21. Neil L, Olsson NC, Pellicano E: The relationship between intolerance of uncertainty, sensory sensitivities, and anxiety in autistic and typically developing children. J Autism Dev Disord. 2016, 46:1962-1973. 10.1007/s10803-016-2721-9

22. Corbett BA, Muscatello RA, Blain SD: Impact of sensory sensitivity on physiological stress response and novel peer interaction in children with and without autism spectrum disorder. Front Neurosci. 2016, 10:278. 10.3389/fnins.2016.00278

23. Kerns CM, Renno P, Kendall PC, Wood JJ, Storch EA: Anxiety disorders interview schedule-autism addendum: reliability and validity in children with autism spectrum disorder. J Clin Child Adolesc Psychol. 2017, 46:86-100. 10.1080/15374416.2016.1233501

24. Uljarević M, Richdale A, Evans DW, Cai RY, Leekam SR: Interrelationship between insistence on sameness, effortful control and anxiety in adolescents and young adults with autism spectrum disorder (ASD). Mol Autism. 2017, 8:36. 10.1186/s13229-017-0158-4

25. South M, Rodgers J: Sensory, emotional and cognitive contributions to anxiety in autism spectrum disorders. Front Hum Neurosci. 2017, 11:20. 10.3389/fnhum.2017.00020

26. Postorino V, Kerns, CM Vivanti G, Bradshaw J, Siracusano M, Mazzone L: Anxiety disorders and obsessivecompulsive disorder in individuals with autism spectrum disorder. Curr Psychiatry Rep. 2017, 19:92. 10.1007/s11920-017-0846-y

27. Hwang YIJ, Arnold S, Srasuebkul P, Trollor J: Understanding anxiety in adults on the autism spectrum: an investigation of its relationship with intolerance of uncertainty, sensory sensitivities and repetitive behaviours. Autism. 2019, 24: 411-422. 10.1177/1362361319868907

28. Bitsika V, Arnold WA, Sharpley CF: The role of sensory features in mediating associations between autism symptoms and anxiety in boys with autism spectrum disorder [Epub ahead of print]. J Autism Dev Disord. 2019, 10.1007/s10803-019-03917-1

29. Craske MG, Rauch SL, Ursano R, Prenoveau J, Pine DS, Zinbarg R: What is an anxiety disorder?. Depress Anxiety. 2009, 26:1066-1085. 10.1002/da.20633

30. Green SA, Ben-Sasson A: Anxiety disorders and sensory over-responsivity in children with autism spectrum disorders: is there a causal relationship?. J Autism Dev Disord. 2010, 40:1495-1504. 10.1007/s10803-0101007-x

31. Green SA, Rudie JD, Colich NL, et.al.: Overreactive brain responses to sensory stimuli in youth with autism spectrum disorders. J Am Acad Child Adolesc Psychiatry. 2013, 52:1158-1172. 10.1016/j.jaac.2013.08.004

32. Dellapiazza F, Vernhet C, Blanc N, Miot S, Schmidt R, Baghdadli A: Links between sensory processing, adaptive behaviours, and attention in children with autism spectrum disorder: a systematic review. Psychiatry Res. 2018, 270:78-88. 10.1016/j.psychres.2018.09.023

33. Green SA, Ben-Sasson A, Soto TW, Carter AS: Anxiety and sensory over-responsivity in toddlers with autism spectrum disorders: bidirectional effects across time. J Autism Dev Disord. 2012, 42:1112-1119. 10.1007/s10803-011-1361-3

34. Mazurek MO, Vasa RA, Kalb LG, et.al.: Anxiety, sensory over-responsivity, and gastrointestinal problems in children with autism spectrum disorders. J Abnorm Child Psychol. 2013, 41:165-176. 10.1007/s10802-0129668-X

35. Glod M, Riby DM, Rodgers J: Short report: relationships between sensory processing, repetitive behaviors, anxiety, and intolerance of uncertainty in autism spectrum disorder and Williams syndrome. Autism Res. 


\section{Cureus}

2019, 12:759-765. 10.1002/aur.2096

36. Bird G, Cook R: Mixed emotions: the contribution of alexithymia to the emotional symptoms of autism .

Transl Psychiatry. 2013, 3:e285. 10.1038/tp.2013.61

37. Bird G, Silani G, Brindley R, White S, Frith U, Singer T: Empathic brain responses in insula are modulated by levels of alexithymia but not autism. Brain. 2010, 133:1515-1525. 10.1093/brain/awq060

38. Green SA, Hernandez L, Tottenham N, Krasileva K, Bookheimer SY, Dapretto M: Neurobiology of sensory overresponsivity in youth with autism spectrum disorders. JAMA Psychiatry. 2015, 72:778-786.

10.1001/jamapsychiatry.2015.0737

39. Ahrens S, Wu MV, Furlan A, et al.: A central extended amygdala circuit that modulates anxiety. J Neurosci. 2018, 38:5567-5583. 10.1523/JNEUROSCI.0705-18.2018

40. Wood JJ, Drahota A, Sze K, Har K, Chiu A, Langer DA: Cognitive behavioral therapy for anxiety in children with autism spectrum disorders: a randomized, controlled trial. J Child Psychol Psychiatry. 2009, 50:224-234. 10.1111/j.1469-7610.2008.01948.x

41. White SW, Oswald D, Ollendick T, Scahill L: Anxiety in children and adolescents with autism spectrum disorders. Clin Psychol Rev. 2009, 29:216-229. 10.1016/j.cpr.2009.01.003

42. Silva LM, Schalock M, Ayres R, Bunse C, Budden S: Qigong massage treatment for sensory and selfregulation problems in young children with autism: a randomized controlled trial. Am J Occup Ther. 2009, 63:423-432. 10.5014/ajot.63.4.423

43. Sanchack KE, Thomas CA: Autism spectrum disorder: primary care principles. Am Fam Physician. 2016, 94:972-979. 